\title{
ПРАВОВАЯ СОЦИАЛИЗАЦИЯ РОССИЙСКОЙ МОЛОДЕЖИ В ПОСТСОВЕТСКИЙ ПЕРИОД: ИНСТИТУЦИОНАЛЬНЫЕ ФАКТОРЫ ТРАНСФОРМАЦИИ
}

\author{
(C) 2019 Канунникова Алла Владимировна \\ кандидат социологических наук, старший преподаватель \\ Институт права, экономики и финансов \\ Кабардино-Балкарский государственный университет им. Х.М. Бербекова \\ 360000, г. Нальчик, ул. Чернышевского, д. 173 \\ E-mail: allakanunnikova@mail.ru \\ (C) 2019 Коцева Азиза Анзоровна \\ Институт права, экономики и финансов \\ Кабардино-Балкарский государственный университет им. Х.М. Бербекова \\ 360000, г. Нальчик, ул. Чернышевского, д. 173 \\ (C) 2019 Арипшев Абубекир Юрьевич \\ Институт права, экономики и финансов \\ Кабардино-Балкарский государственный университет им. Х.М. Бербекова \\ 360000, г. Нальчик, ул. Чернышевского, д. 173 \\ (c) 2019 Дабагов Роберт Романович \\ Институт права, экономики и финансов \\ Кабардино-Балкарский государственный университет им. Х.М. Бербекова \\ 360000, г. Нальчик, ул. Чернышевского, д. 173
}

В статье исследуется правовая социализация российской молодежи с 90-х г.г., играющая важную роль в развитии правовой и социальной системы социума. Отмечается, что для кардинального изменения негативных социальных трендов в сфере выработки у молодых людей навыков правового поведения необходимы комплексные социологические исследования социально-правовых процессов и переход к научно-обоснованному регулированию процессов правовой социализации молодежи.

Ключевые слова: право, социализация, российская молодежь, социально-правовые процессы, правовое развитие.

Современная Россия в очередной раз стоит перед задачами формирования эффективной демократии, воспитания нового типа молодого гражданина, знающего и умеющего отстаивать свои права, а также соблюдать права других людей. Эти задачи предполагают формирование нового типа эффективной правовой политики и институтов правовой социализации молодежи. Правовая социализация играет важную роль в развитии правовой и социальной системы социума.

Социальные процессы правовой социализации определяются не столько нормативными требованиями со стороны государства (которое, как ожидается, постепенно станет правовым), сколько социальными ожиданиями, неформальными нормами и социальными стереотипами по отношению к праву и правовым ценностям и институтам, которые доминируют в общественном сознании. Эти процессы также зависят от динамики трансформации общественного сознания в текущий исторический период, поскольку, как указывает А.В. Дука [1], «институты предполагают историчность».

Невозможно внезапно изменить сознание людей, сделать его более «правовым» или, наоборот, «неправовым». Формирование правовых установок и ценностей занимает большой исторический период, в котором каждый предшествующий этап, характер социально-правовых процессов, протекающих в нем, основные вызовы, с которыми справлялись проживающие в нем люди, и допущенные ими ошибки напрямую влияют на последующее правовое развитие 
страны.

Этот раздел институциональной теории называется «раth dependence». Это направление популярно не только в западных, но и в российских академических кругах. В нем рассматривается, как прошлые социальные действия и характер тех или иных исторических событий влияют на настоящий выбор людей. После прохождения некоторого временного диапазона, процесс институционального изменения становится необратимым, поскольку общество фактически не может свернуть «с колеи», а альтернативные варианты исторических действий становятся невозможными. Общество фактически замыкается на исторически сложившихся выборах, и диапазон этих выборов определяется предшествующим историческим развитием.

Решение неоинституционалисты видят в необходимости выработки поведенческих алгоритмов или схем поведения, являющихся в модернизационных условиях наиболее эффективными. Данные институты могут создаваться гражданским обществом, государством и самими гражданами. Тогда в последующем правовое развитие российского социума будет проходить с меньшими историческими издержками.

Российские исследователи [2], придерживающиеся институциональной методологии, полагают, что социальные процессы, включая те, которые происходят в правовой и экономической сферах, определяются особенностями российской социокультурной системы.

Советские конституции закрепляли определенный набор прав и свобод личности. Советское правозащитное движение началось с лозунгов: «Соблюдайте Ваши законы!», «Соблюдайте Вашу Конституцию!». Воздействовать на власть советские граждане должны были не в виде протестов, а с помощью письменных жалоб. Двойственная правовая мораль разрушала правовое поведение и правовые стереотипы в советском народе. По формальному законодательству ему гарантировалась большая часть прав т.н. «второго» и «третьего» эшелонов. Это социальные и экономические права, включая право на защиту от безработицы, право на бесплатную медицинскую помощь и даже право на бесплатное жилье. Но фактически реализовать эти права могли весьма немногие. Некоторые получали возможность реализовать ограниченный объем предусмотренных в Советском Союзе прав. Другие действовали в сфере неформальной экономики, предпочитая, например, давать взятку врачу за оказание качественной медицинской помощи, чем требовать от него реализации своих прав с Конституцией Советского Союза на руках.

Негативные институциональные паттерны соответствующим образом повлияли на развитие советского правоведения. Граждан Советского Союза никто не учил отстаивать свои права, писать жалобу в надзорные органы, обращаться с кассацией. Большая часть юристов после получения диплома соответствующего вуза уходила работать в органы правопорядка и государственной безопасности [3]. Профессия адвоката не считалось престижной, а суд и обвинение действовали фактически на одной стороне.

Если же индивид был не согласен терпеть правовой произвол в отношении себя и своих близких, если он пытался хоть как-то исправить сложившуюся негативную ситуацию с реализацией его жизненно важных прав (например, получить положенное ему по закону жилье или квалифицированную и высококачественную медицинскую помощь), против таких людей использовалась сила общественного мнения. Таких людей называли «сутяжниками». Их обвиняли в том, что они «оторвались от общества и коллектива». Иногда их обвиняли в том, что они выступают против советского строя. В таких случаях было возможно ответное уголовное преследование. Поэтому некоторые социально активные люди предпочитали уезжать из Советского Союза, эмигрируя в Германию, Канаду, США, Израиль, Австрию и пр.

Схожие негативные стереотипы общественного мнения действуют по отношению ко многим российским правозащитникам и гражданским активистам. Многие гражданские активисты выходят на акции протеста с такими же лозунгами, как это было в Советском Союзе. Они призывают соблюдать статьи Конституции Российской Федерации, указывают на недопустимость политических репрессий и произвольного административного задержания и пр.

До сих пор в российском обществе весьма немногие полагают, что правозащитник может защищать права и свободы пострадавших, не потому, что ему за это платят гранты или пожертвования западных фондов, а потому, что он ощущает себя гражданином, что у него высокий уровень гражданского самосознания. Существующие пока общественные стереотипы и институциональные паттерны не позволяют сделать 
профессии правозащитника и гражданского активиста почетными и уважаемыми, как, например, профессии прокурора или судьи.

Длительный период доминирования правового нигилизма в 1990-е годы фактически деформировал общественное сознание. Право до сих пор воспринимается как дополнительный или вспомогательный социальный институт, а неправовое поведение во многом является вещью обыденной и повседневной. С подобными негативными социальными проявлениями российское общество сталкивается уже более четверти века.

В российском общественном сознании право не осмысливается как «свобода», и многие молодые люди указывают скорее на желательность правового обучения, но понимают его незначительность для осуществления жизненных планов.

В вопросах правового поведения и соблюдения законов для молодых россиян характерны адаптационная и поведенческая гибкость, а также ценностный релятивизм. Молодые люди даже на уровне деклараций не демонстрируют особую приверженность соблюдению буквы и духа закона. Большая часть молодежи стремится решать свои проблемы способами, которые социологи называют «неправовыми» институциональными практиками.

Эти данные подтверждают результаты региональных социологических исследований [4]. Молодежь (до 25 лет) - это часть общества, наименее озабоченная проблемой построения правового государства, развития правовых ценностей и институтов. Многие молодые люди не считают, что несоблюдение прав является реально существующей проблемой.

Молодые люди не желают заниматься тем, что не приносит реальной пользы. В структуре предпочтений молодежи значимое место занимают ценности времяпровождения, достижения экономического достатка и т.п. Ее готовность жертвовать своими интересами во имя улучшения жизни общества в длительной перспективе носит слабовыраженный характер, а ее правовое сознание представляет собой неустойчивый социально-психологический комплекс разносторонних идей.

Стремление добиться успеха не сопровождается желанием совершенствовать навыки, пусть даже не в правовой сфере, а в профессиональной. Как указывает Ж.Т. Тощенко [5], «желание хорошо зарабатывать никак не коррелирует со стремлением совершенствовать знания и навыкИ».

Для современной молодежи характерен низкий уровень правовых знаний. Они не представляют, что такое правовые процедуры, не знают, куда обратиться в случае, если их права были нарушены, как защитить себя в случае преследования со стороны государственных органов и т.п.

Одна из очевидных институциональных причин в том, что, как показывают социологические исследования Фонда «Общественное мнение» [6], большинство жителей страны убеждены: наиболее важные для людей права (право на труд и его справедливую оплату, равенство перед законом и право на бесплатную медицинскую помощь, бесплатное образование) не соблюдаются (63\%). Каждый пятый опрошенный (21\%) указывает, что его права в той или иной степени нарушались. 57\% респондентов подчеркивают, что в России плохо соблюдается право на труд и его справедливую оплату, 56\% полагают, что не соблюдается право на равенство перед законом и право на справедливый суд. Столько же (56\%) опрошенных россиян считают, что в стране плохо реализуется право на бесплатную медицинскую помощь. Каждый второй (50\%) отметил, что не реализуется право на бесплатное образование. 37\% полагают, что плохо реализуется право на социальное обеспечение.

Чуть более оптимистичными являются респонденты, опрошенные сотрудниками Фонда «Общественное мнение», по вопросам политических и гражданских прав 32\% полагают, что не реализуется право на участие в управлении обществом и государством. 27\% не видят в России реализации права на свободу собраний, манифестаций, митингов и демонстраций. 22\% полагают, что серьезно ограничено право на свободу слова. Столько же (22\%) респондентов отмечают фактические ограничения избирательных прав граждан. 21\% полагают, что не соблюдается право на неприкосновенность собственности и жилья. $18 \%$ согласны с точкой зрения, что в стране не соблюдаются права на личную свободу и неприкосновенность. $11 \%$ - что не соблюдаются свобода передвижения и право на выбор места проживания, очевидно, подразумевая миграционные и регистрационные ограничения. 51\% опрошенных московскими социологами полагают, что ситуация с соблюдением в России прав человека не изменилась, 23\% считают, что ухуд- 
шилась, противоположного мнения придерживается $12 \%$ опрошенных.

Другие институциональные причины, негативно влияющие на правовое поведение молодежи, можно отнести к структурным дефектам деятельности системы образования. Как социальный феномен правовая грамотность доступна эмпирическому изучению, исследованиям характера влияния различных социальных институтов на правовое поведение.

Е. Головченко подчеркивает, что у современных молодых людей образовался ценностный вакуум [7]. Многие молодые люди не доверяют правоохранительной системе во многом потому, что она не готова адекватно удовлетворять правовые потребности молодежи. Ряд правовых процедур (например, судебных) являются чересчур затянутыми.

Сами правоохранительные органы не воспринимаются как «слуги народа», содержание которых осуществляется через бюджетное финансирование. Скорее, напротив, защита прав рассматривается как некоторая милость со стороны чиновников в случаях, когда они готовы отказаться от фаворитизма, привилегий, принуждения, которое им приносит неправовое поведение, или, наоборот, придерживаться честности и законопослушания в случаях, когда им это экономически невыгодно.

Наблюдая за негативными социальными и правовыми явлениями, все больше молодых людей убеждается в том, что право в современной России - это социальная фикция и социальный фантом, формальные правовые институты не работают, а договариваться о решении социально-правовых коллизий и экономических проблем нужно всегда на неформальном уровне «по понятиям».

В результате растет социальная апатия молодежи, некоторая часть молодежной среды криминализируется и радикализируется, в общественном сознании увеличивается безразличное отношение к праву. Региональные социологи отмечает, что значительно увеличилось количество молодых людей, неуважительно относящихся к закону. По мнению Е.А. Красновой, которая провела социологическое исследование в Свердловской области, каждый второй молодой человек нарушает те или иные правовые нормы, многие молодые люди лояльно относят- ся к употреблению наркотиков, а более 30\% считают допустимым употребление «легких наркотиков» [8].

Вместе с тем молодежь обладает значительным креативным потенциалом, который используется не в полной мере. Молодые люди по сравнению со старшими поколениями более мобильны, инициативны, восприимчивы к социальным изменениям, принятию новых технологий, способны и пр. Однако использовать этот позитивный социальный потенциал у государства пока не получается.

Социальное и экономическое развитие российского государства в значительной мере зависит от правового поведения и правовой компетентности его граждан. «В целом, всеобщность права как единого и равного (для того или иного круга отношений) масштаба и меры (а именно меры свободы) означает отрицание произвола и привилегий (в рамках этого правового круга)» [9].

Среди позитивных социально-правовых процессов можно указать на получившие в последние годы распространение такие новые институциональные формы правовой социализации, как Интернет - форумы и видеоблоги. На них подписывается значительное количество молодежи, чтобы послушать выступления ведущих правозащитников и адвокатов страны. Обычно финансовая поддержка таким программам предоставляется независимыми фондами поддержки социальных и гражданских инициатив и ресурсными центрами. Иногда финансово помогает бизнес. Такие институциональные механизмы предполагают возможность обращения молодого человека со своей проблемой через Интернет - приемные соответствующих правозащитных и гражданских организаций.

Программы «виртуальной» правовой социализации направлены на увеличение социального вклада молодого поколения в правовое развитие страны путем перевода молодежи из пассивных слушателей лекций, коллоквиумов и семинаров в активных субъектов правовых отношений. Это будет способствовать максимальному использованию интереса молодых граждан к вопросам развития права, правовых институтов и развития правового государства в интересах гражданского общества. 


\section{Библиографический список}

1. Дука А.В. Перспективы социологического анализа властных элит // Журнал социологии и социальной антропологии. 2000. Т. III. № 1.

2. Кирдина С.Г. Институциональные матрицы: макросоциологическая объяснительная гипотеза // Социс. 2001. № 2.

3. Канунникова А.В. Институциональные факторы трансформации правовой социализации молодежи в условиях модернизации российского общества: диссертация ... кандидата социологических наук: 22.00.04 / Канунникова Алла Владимировна; [Место защиты: Федеральное государственное автономное образовательное учреждение высшего образования «Южный федеральный университет», http://www.sfedu.ru/].Ростов-на-Дону, 2015.- 168 с.

4. Асланов Я.А., Барбашин М.Ю., Барков Ф.А., Крамарова Е.Н. (рук. авт. колл.), Янакова Е.В. Комплексный портрет студентов Южного федерального университета. Ростов-на-Дону. 2013. 288 с.

5. Тощенко Ж. Т. Парадоксальный человек. Москва. 2001. С. 149.

6. Исследование “Права человека в России” (www.fom.ru/Tsennosti/10873 Доступ 30.10.2014). Источник данных “ФОМнибус" - опрос граждан России от 18 лет и старше. 10 марта 2013 года. 43 субъекта России. 100 населенных пункта, 1500 респондентов, интервью по месту жительства. Статистическая погрешность не превышает $3,6 \%$.

7. Головченко Е. Проблемы молодежи и ее ценностные ориентации в современных условиях (на примере Красноселькупского района Ямало-Ненецкого автономного округа) // Власть. 2007. № 7. С. 53.

8. Краснова Е.А. Нравственные ориентации молодежи в условиях стихийной социализации // Социология. 2006. № 2. с. 36.

9. Нерсесянц В.С. Философия права. Москва. 1997. С. 23.

Поступила в редакцию 15.01.2019 